\title{
The Effect of Macroeconomy Towards The Infrastructure, Utilities, and Transportation Sector's Stock Return in The Indonesian Stock Exchange
}

\author{
Frido Saritua Simatupang ${ }^{1}$, Sofia Windiarti ${ }^{2}$ \\ \{frido.s@lecture.unjani.ac.id ${ }^{1}$, sofiawindiarti@yahoo.co.id²\} \\ Faculty of Economics and Business, Jenderal Achmad Yani University, Indonesia ${ }^{1}$, Faculty of \\ Economics and Business, Jenderal Achmad Yani University, Indonesia ${ }^{2}$
}

\begin{abstract}
This study aims to identify the effect of macroeconomic variables on stock returns, where macroeconomic fluctuations can affect stock prices and have an impact on stock returns. The macroeconomic variables used in this study are inflation, interest rates (BI rate), and the Rupiah exchange rate against the US Dollar. The population used by researchers is the Infrastructure, Utilities, and Transportation sector in the Indonesian Stock Exchange with a population of 60 companies. The sampling technique used was purposive sampling in order to obtain 37 sample companies. The data processing technique that is used is panel data. The results showed that simultaneously there was a macroeconomic influence on stock returns, and partially there was a significant negative effect between inflation and exchange rates on stock returns, while the interest rate (BI rate) had no effect on stock returns.
\end{abstract}

Keywords: Inflation; exchange rate; stock returns; interest rate.

\section{Introduction}

The investment climate of a country is usually influenced by its high or low macroeconomic conditions. Large investment risk means that high inflation will have an adverse impact on the rate of return of an investment. If inflation is high, the prices of goods and services will tend to increase. This increase will affect the decline in market demand, which results in decreased sales and has an impact on company revenues Suyati [1]

The interest rate has a negative relationship to stock return; if the interest rates on credit experience increase, then the stock return will decline, and this also works in reverse. If the interest rate decreases, the stock return will increase. This is caused because when the interest rate loans go up, owners tend to their capital to the form of deposits that could adversely affect stock prices in the capital market.

When the Rupiah exchange rate depreciates against the US Dollar, it will affect companies that rely on imported materials. This means that the material price will increase and will affect the selling price of the product and have an impact on market demand. When market demand falls, it will affect the company's performance 
Research on factors that affect stock returns has been carried out by many upstream researchers, in this case, is macroeconomic, but the results of the study showed mixed results. This means that researchers have not pinpointed to which macroeconomic variable can most dominantly affect stock returns.

Research conducted by Suyati [1], Asri and Suwarta [2], Jamaludin, et al [3], and Amrillah [4] states that inflation has a negative effect on stock returns. This is in contrast to the results of researches that were conducted by Menina [5], Mahilo and Parengkuan [6], Sutrisno [7], Nisha [8], and Andes, et al [9], who found that there is no influence between inflation and stock returns. Meanwhile, research conducted by Ndlovu, et al [10], Kibria et al., [11], Alam and Rashid [12], and Ouma and Muriu [13] stated that inflation has a positive effect on company stock returns in Johannesburg, South Africa.

Suyati [1], Sutrisno [7], Ndlovu, et al [10], and Jamaludin, et al [3] in their research results state that deposit rates have a negative effect on stock returns. The results of this study contradict the results of research conducted by Asri and Suwarta [2], Mahilo and Parengkuan [6], Barakat, et al [14], Ouma and Muriu [13], and Andes, et al [9] who mentioned that sump deposit rates did not have a negative effect on the return stock.

Suyati [1], Amrillah [4], Sutrisno [7], Ndlovu, et al [10], and Andes, et al [9] in their research results state that exchange rates have a negative effect on stock returns. This statement was in contrast to the results of research by Mahilo and Parengkuan [6], Barakat, et al [14], Gay, et al [15], where the results show that there is no negative influence between exchange rates on stock returns. Moreover, Kibria, et al [11] stated in their research that the exchange rate positively affects stock returns in Pakistan.

Based on the gap analysis above, the following research questions are formed:

1. Does macroeconomy influence the stock returns in infrastructure, utilities, and transportation companies in the IDX?

2. Does inflation affect stock returns in infrastructure, utility, and transportation companies on the IDX?

3. Does the interest rate (BI rate) affect the stock returns of infrastructure, utility, and transportation companies on the IDX?

4. Does the exchange rate affect stock returns in infrastructure, utility, and transportation companies in BEI?

The purpose of this study was to determine the simultaneous and partial effect of macroeconomy (inflation, interest rates, and exchange rates) on stock returns.

\subsection{The Effect of Inflation on Stock Returns}

If a country's inflation is out of control, it will have an impact on reducing people's purchasing power for goods and services. The decrease of purchasing power will influence the performance of the company, which will have an effect also on the decline in stock prices, for which, in turn, the stock returns will go down too.

Suyati [1] and Asri and Suwarta [2] mentions that inflation gives a negative effect on the return of shares, which means that when inflation increases and not controlled, then it will have an impact on the decline in the return of shares resulting from the decrease in the price of the stock. The results of their studies are supported by research conducted by Amrillah [4], Jamaludin, et al [3], Kabeer, et al [16], and Gay, et al [15]. 


\subsection{The Effect of Interest Rates on Stock Returns}

Suyati [1] and Sutrisno [7], in their research, explain that interest rates negatively affect the return of the company's shares. The same thing was conveyed by Jamaludin, et al [3]. They stated that interest rates have a negative effect on company stock returns in ASEAN countries, of which was unlike Nisha [8] research result, who indicated that interest rates have a negative impact on stock returns companies in India.

\subsection{The Effect of Exchange Rates on Stock Returns}

The exchange rate is one of the macroeconomic variables that could impact the volatility of companies' stock prices. The depression of domestic currency will increase the country's export volume. Suyati [1], Amrillah [4], Sutrisno [7], and Andes, et al [9] in their research results state that the Rupiah exchange rate against the US Dollar has a negative effect on companies' stock returns. This research was supported by Ndlovu, et al [10], which stated that the South African currency exchange rate (Rand) had an effect on stock returns. The same thing was conveyed by Kabeer, et al [16], Nisha [17], Ouma and Muriu [13], Abbas, [17], and Alam and Rashid [12].

\subsection{Research Model}

Based on the previous research above, the research model can be described as follows:

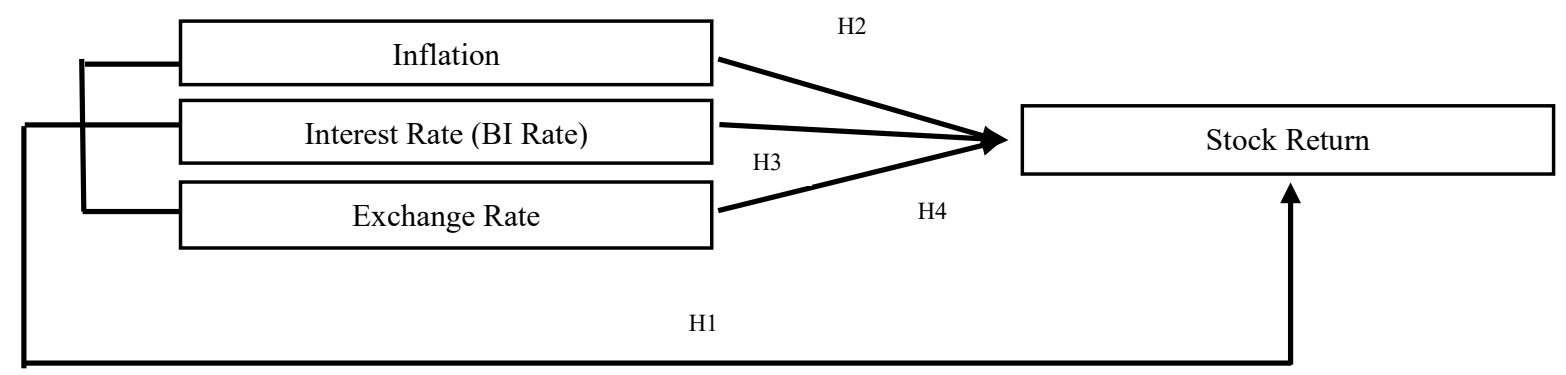

Fig 1. Research Model

Based on the research model above, the following hypotheses are formulated:

H1: Macroeconomy can affect stock returns

$\mathrm{H} 2$ : Inflation has a negative effect on stock returns

H3: Interest rates have a negative impact on stock returns

H4: Exchange rates have a negative impact on stock returns

\section{Researh Method}


The research method in this study is the multiple regression analysis. The data sources that were used are secondary data, comprising of monthly data derived from the financial statements of companies in the infrastructure, utilities, and transportation sector in the IDX period of 2014 to 2018, monthly closing price, monthly inflation data, annual interest rate which were interpolated to monthly data, and exchange rate data taken at the end of each month. The type of data used is panel data. The population in this study were companies in the infrastructure, utility, and transportation sectors on the IDX for the 2014-2018 period, for as many as 60 companies. The sampling technique used is purposive sampling, namely the selection of research samples based on specific considerations. The considerations are (1) issuers were already listed in the Stock Exchange during the period of research and (2) actively traded during the study period. Through these criterias, the sample size was narrowed to 37 companies. The research variables consist of stock return as the dependent variable and inflation, interest rates, and measurement value as the independent variable. The test tool that was used is Eviews version 6.

\section{Results and Discussion}

\subsection{Descriptive Analysis}

Descriptive analysis is a characteristic of the examined variables. It is used to determine the minimum value, maximum value, average value, and standard deviation of the studied variables:

Table 1. Descriptive analysis

\begin{tabular}{|l|c|c|c|c|}
\hline & $\mathbf{Y}$ & $\mathbf{X 1}$ & $\mathbf{X 2}$ & $\mathbf{X 3}$ \\
\hline Mean & 0.019691 & 4.717833 & 6.145833 & 13333.67 \\
\hline Median & 0.000000 & 3.809167 & 6.000000 & 13465.42 \\
\hline Maximum & 0.712366 & 6.419167 & 7.541667 & 14337.83 \\
\hline Minimum & -0.157058 & 3.197500 & 4.562500 & 11943.92 \\
\hline Std. Dev. & 0.110657 & 1.395229 & 1.224153 & 776.3833 \\
\hline Skewness & 4.061088 & 0.330396 & 0.023793 & -0.716129 \\
\hline Kurtosis & 23.42004 & 1.219247 & 1.335449 & 2.642482 \\
\hline Jarque-Bera & 3722.721 & 27.80956 & 21.37517 & 16.79786 \\
\hline Probability & 0.000000 & 0.000001 & 0.000023 & 0.000225 \\
\hline Sum & 3.642866 & 872.7992 & 1136.979 & 2466728. \\
\hline Sum Sq. Dev. & 2.253064 & 358.1862 & 275.7335 & $1.11 \mathrm{E}+08$ \\
\hline Observations & 185 & 185 & 185 & 185 \\
\hline
\end{tabular}

Source: Data Processing Results

Based on Table 1 above, it is known that the lowest inflation is $3.198 \%$, and the highest is $6.419 \%$. The average inflation rate is $4.718 \%$, which means that inflation is concentrated at $4.718 \pm$ 1.395. Meanwhile, the lowest interest rate is $4.563 \%$, and the highest is $7.542 \%$, with the average in 
the $2014-2018$ period was $6.146 \%$ with a standard deviation of $1.224 \%$. This indicates that the interest rate for the period 2014-2018 is centered at $6.146 \pm 1.224 \%$.

At the same time, the lowest exchange rate was IDR 11,943.92, and the highest was IDR $14,337.83$, with the average was $13,333.67$ with a standard deviation of IDR 776.38 . This shows that the exchange rate data is centered on the figure of IDR 13.333.67 \pm 776.383 . Then, the lowest stock return in the same period was -0.157 points and the highest was 0.712 points. The average stock return index was 0.020 points with a standard deviation of 0.111 points, which shows that the stock returns data is centered at $0.020 \pm 0.111$ points.

\subsection{Hypothesis Testing}

\subsubsection{Simultaneous Hypothesis Testing}

Simultaneous hypothesis testing is used to determine whether there is an effect of inflation, interest rates, and exchange rates on stock returns. The test criteria stated that if the probability $<$ level of significance $(\alpha)$, then there is a significant effect simultaneously between inflation, interest rates, and exchange rates on stock returns.

Table 2. Result of F Testing (Simultaneously)

\begin{tabular}{lrlrr}
\hline \hline \multicolumn{1}{c}{ Variable } & Coefficient & Std. Error & t-Statistic & Prob. \\
\hline \hline X1 & -0.037839 & 0.015841 & -2.388690 & 0.0179 \\
X2 & 0.021614 & 0.016551 & 1.305924 & 0.1932 \\
X3 & $-5.55 \mathrm{E}-05$ & $1.42 \mathrm{E}-05$ & -3.921271 & 0.0001 \\
C & 0.806024 & 0.217381 & 3.707883 & 0.0003 \\
\hline \hline & & & & \\
R-squared & 0.083537 & Mean dependent var & & 0.019691 \\
Adjusted R-squared & 0.068347 & S.D. dependent var & & 0.110657 \\
S.E. of regression & 0.106808 & Akaike info criterion & & -1.614179 \\
Sum squared resid & 2.064849 & Schwarz criterion & & -1.544549 \\
Log likelihood & 153.3115 & Hannan-Quinn criter. & & -1.585959 \\
F-statistic & 5.499500 & Durbin-Watson stat & & 1.967156 \\
Prob(F-statistic) & 0.001227 & & \\
\hline \hline
\end{tabular}

Source: E-Views processing results, 2019 
Simultaneous hypothesis testing resulted in the value of $\mathrm{F}_{\text {statistic }}=5.499$ with a probability of 0.001 . This result shows that the probability $<$ level of significance $(\alpha=5 \%)$. This means a significant effect of inflation, interest rates, and exchange rates on stock returns.

\subsubsection{Partial Hypothesis Testing}

Partial hypothesis testing is used to determine whether there is an effect of inflation, interest rates, and exchange rates on stock returns. The test criteria stated that if the regression coefficient is positive and probability $<$ level of significance $(\alpha)$, then there are a significant individual effect of inflation on stock returns, a significant individual effect of interest rates on stock returns, and a significant individual effect of the exchange rate on stock returns.

Table 3. Results of T Testing (Partial)

\begin{tabular}{|c|c|c|c|c|}
\hline \multicolumn{5}{|c|}{$\begin{array}{l}\text { Dependent Variable: } Y \\
\text { Method: Panel Least Squares } \\
\text { Date: } 01 / 09 / 20 \text { Time: } 22: 44 \\
\text { Sample: } 20142018 \\
\text { Periods included: } 5 \\
\text { Cross-sections included: } 37 \\
\text { Total panel (balanced) observations: } 185\end{array}$} \\
\hline Variable & Coefficient & Std. Error & t-Statistic & Prob. \\
\hline $\mathrm{X} 1$ & -0.037839 & 0.015841 & -2.388690 & 0.0179 \\
\hline $\mathrm{X} 2$ & 0.021614 & 0.016551 & 1.305924 & 0.1932 \\
\hline X3 & $-5.55 E-05$ & $1.42 \mathrm{E}-05$ & -3.921271 & 0.0001 \\
\hline $\mathrm{C}$ & 0.806024 & 0.217381 & 3.707883 & 0.0003 \\
\hline
\end{tabular}

Source: E-Views processing results, 2020

\subsubsection{Partial Hypothesis Testing of Inflation on Stock Returns}

Partial hypothesis testing of inflation on stock returns produces a $t_{\text {statistic }}$ value of $-2,389$ with a probability of 0.018 . The test results show the probability $<$ level of significance $(\alpha=5 \%)$. This indicates that there is a significant negative effect of inflation on stock returns. The results of this study are supported by research conducted by Suyati [1], Asri and Suwarta [2], Amrillah [4], Kabeer, et al [16], Gay, et al [15], and Jamaludin, et al [3], which state that an increase in inflation has a negative effect on stock returns.

\subsubsection{Partial Hypothesis Testing of Interest Rates on Stock Returns}

The partial hypothesis testing of interest rates on stock returns results in a $t_{\text {statistic }}$ value of 1.306 with a probability of 0.193 . The test results show the probability $>$ level of significance $(\alpha=5 \%$ ). This signifies that there is no significant effect of interest rates on stock returns. The results of this study are supported by research conducted by Asri and Suwarta [2], Mahilo and Parengkuan [6], Barakat, et al [14], Ouma and Muriu [13], and Andes, et al [9], which state that interest rates deposit has no negative effect on stock returns. 


\subsubsection{Partial Hypothesis Testing of Exchange Rates on Stock Returns}

The partial hypothesis testing of the exchange rate on stock returns results in a $t_{\text {statistic }}$ value of -3.921 with a probability of 0.000 . The test results show the probability $<$ level of significance $(\alpha=$ $5 \%$ ). This indicates that there is a partially significant negative effect of exchange rates on stock returns. This result is supported by research conducted by Suyati [1], Amrillah [4], Sutrisno [7], Ndlovu, et al [10], Andes, et al [9], Kabeer, et al [16], Nisha [17], Ouma and Muriu [13], Abbas, et al [17], and Alam and Rashid [12].

\subsubsection{Empirical Model of Regression Panel}

The regression equation from the estimation results of regression panel analysis is:

\section{Common Effect Model}

$\rightarrow$ Stock return $=0.806-0.038$ Inflation +0.022 Interest rates $-5.55 \times 10^{-5}$ Exchange rates (1) This equation shows the following:

a) A constant value of 0.806 indicates that if inflation, interest rates, and exchange rates are constant (fixed), stock returns will be 0.806 points.

b) The inflation coefficient of -0.038 indicates that inflation has a negative and insignificant effect on stock returns. This means that an increase in inflation of $1 \%$ will reduce the stock return by 0.038 points.

c) The interest rate coefficient of 0.022 indicates that interest rates have a positive and insignificant effect on stock returns. This means that if there is an increase in interest rates by $1 \%$ rupiah, it will increase stock returns by 1.074 points, even though the increase is not significant.

d) The exchange rate coefficient of $-5.55 \times 10^{-5}$ indicates that the exchange rate has a negative and significant effect on stock returns. This means that an increase in the exchange rate of 1 rupiah will reduce the stock return by $5.55 \times 10^{-5}$ points.

\section{Conclusions and Suggestions}

\subsection{Conclusion}

Based on the results and discussion above, it can be concluded that, simultaneously, there are effects of inflation, interest rates, and exchange rates on stock returns. However, the inflation and exchange rate variables only partially affect stock returns, while another macro variable, namely interest rates, does not affect stock returns.

\subsection{Suggestions}

Based on the conclusions in the previous sub-chapter, we suggest the following:

1. Advice for investors / potential investors

Macroeconomic conditions in a country are very dynamic. Therefore, investors and potential investors should pay attention to issues related to macroeconomics before making investment decisions.

2. Advice for future researcher 
Researchers suggest examining other variables besides inflation, interest rates, and exchange rates in future research. They could be population growth, the circulation of money, and other macro issues.

\section{Acknowledgements}

Acknowledgements. The researchers are very grateful for the support from LPPM Unjani for the full funding of this research. We also thank Dr. V. Santi Paramita, SE., M.Si, and Dr. Heni Nurani H., SE., M.Si, as Unjani's internal reviewers who have provided many inputs in the completion of this research.

\section{Reference}

[1] S. Suyati, "Pengaruh Inflasi , Tingkat Suku Bunga Dan Nilai Tukar Rupiah / Us Dollar Terhadap Return Saham Properti Yang Terdaftar Di," J. Ilm. UNTAG Semarang, vol. 4, no. 3, pp. 70-86, 2015.

[2] I. G. A. A. Y. Asri and I. K. Suwarta, "Pengaruh Faktor Fundamental Dan Ekonomi Makro Pada Return Saham Perusahaan Consumer Good," E-Jurnal Akunt. Univ. Udayana, vol. 8, no. 3, pp. 353$370,2014$.

[3] N. Jamaludin, S. Ismail, and S. A. Manaf, "Macroeconomic Variables and Stock Market Returns: Panel Analysis from Selected ASEAN Countries," Int. J. Econ. Financ. Issues, vol. 7, no. 1, pp. 37 45, 2017.

[4] M. F. Amrillah, "Pengaruh Nilai Tukar Rupiah (Kurs), Inflasi Dan Pertumbuhan Ekonomi Terhadap Return Saham Pada Perusahaan Perbankan Yang Terdaftar Di Bursa Efek Indonesia (Bei) Periode 2008-2014," J. Valuta, vol. 2, no. 2, pp. 232-250, 2016.

[5] D. D. . Menina, "Pengaruh Nilai Tukar Rupiah, Suku Bunga SBI, Volume perdagangan Saham, Inflasi, dan Beta Saham terhadap Harga Saham," Universitas Diponegoro, 2009.

[6] M. B. Mahilo and T. Parengkuan, "Perusahaan Makanan Dan Minuman Yang Go Public Di Bursa Efek Indonesia,” J. EMBA, vol. 3, no. 3, pp. 1-10, 2015.

[7] B. Sutrisno, "Macroeconomic Variables And Sectoral Indices: Case In The Indonesian Stock Exchange," J. UIN Jakarta Etikonomi, vol. 16, no. 1, pp. 71-80, 2017.

[8] N. Nisha, "Impact of Macroeconomic Variables on Stock Returns : Evidence from Bombay Stock Exchange ( BSE )," J. Invest. Manag., vol. 4, no. 5, pp. 162-170, 2015.

[9] S. L. Andes, Z. Puspitaningtyas, and A. Prakoso, "Digital Digital Repository Repository Universitas Universitas Jember Jember Digital Digital Repository Repository Universitas Universitas Jember Jember," J. Politek. Caltex Riau, vol. 10, no. 2, 2017.

[10] B. Ndlovu, F. Faisal, N. G. Resatoglu, and T. Türsoy, "The Impact of Macroeconomic Variables on Stock Returns : A Case of the Johannesburg Stock Exchange," Rom. Stat. Rev., no. 2, pp. 87-104, 2018.

[11] U. Kibria, Y. Mehmood, M. Kamran, M. U. Arshad, R. Perveen, and M. Sajid, "The Impact of Macroeconomic Variables on Stock Market Returns : A Case of Pakistan,” Res. J. Manag. Sci., vol. 3 , no. 8, pp. 1-7, 2014.

[12] Z. Alam and K. Rashid, "Time Series Analysis of the Relationship between Macroeconomic Factors 
and the Stock Market Returns in," J. Yasar Univ., vol. 9, no. 36, 2014.

[13] W. N. Ouma and P. Muriu, "The Impact Of Macroeconomic Variables On Stock," Int. J. Bus. Commer., vol. 3, no. 11, pp. 1-31, 2014.

[14] M. R. Barakat, S. H. Elgazzar, and K. M. Hanafy, "Impact of Macroeconomic Variables on Stock Markets : Evidence from Emerging Markets," Int. J. Econ. Financ., vol. 8, no. 1, pp. 195-207, 2016.

[15] R. D. Gay, E. Rates, O. Prices, and S. Prices, "Effect Of Macroeconomic Variables On Stock Market Returns For Four Emerging Economies: Brazil, Russia, India, And China,” Int. Bus. Econ. Res. J., vol. 15, no. 3, pp. 1-8, 2016.

[16] M. A. Kabeer, A. Iqbal, R. Najaf, and K. Najaf, "The Influences Of Macro-Economic Factors On Capital," Int. J. Res. Granthaalayah, vol. 4, no. 2, 2016.

[17] S. Abbas, S. H. Tahir, and S. Raza, "Impact of Macroeconomic Variables on Stock Returns : Evidence from KSE-100 Impact of Macroeconomic Variables on Stock Returns : Evidence from KSE-100 Index of Pakistan," Int. Journal's Res. J. Econ. Bus. Stud., vol. 3, no. 7, pp. 70-77, 2014. 